\title{
Phytophthora Species Are Common on Nursery Stock Grown for Restoration and Revegetation Purposes in California
}

\author{
S. Rooney-Latham, ${ }^{1, \dagger}$ C. L. Blomquist, ${ }^{1}$ K. L. Kosta, ${ }^{2}$ Y. Y. Gou, ${ }^{1}$ and P. W. Woods ${ }^{1}$ \\ ${ }^{1}$ California Department of Food and Agriculture, Plant Pest Diagnostics Center, Sacramento, CA 95832; and ${ }^{2}$ California Depart- \\ ment of Food and Agriculture Nursery Program, Sacramento, CA 95814
}

\begin{abstract}
Phytophthora tentaculata was detected for the first time in North America in 2012 in a nursery on sticky monkeyflower plant (Diplacus aurantiacus) and again in 2014 on outplanted native plants. At that time, this species was listed as a federally actionable and reportable pathogen by the USDA. As a result of these detections, California native plant nurseries were surveyed to determine the prevalence of Phytophthora species on native plant nursery stock. A total of 402 samples were collected from 26 different native plant nurseries in California between 2014 and 2016. Sampling focused on plants with symptoms of root and crown rot. Symptomatic tissue was collected and tested by immunoassay, culture, and molecular techniques (PCR). Identifications were made using sequences from the internal transcribed spacer (ITS) rDNA region, a portion of the trnM-trnP-trnM, or the atp9-nad9 mitochondrial regions. Phytophthora was confirmed from 149 of the 402 samples (37\%), and from plants in 22 different host families. P. tentaculata was the most frequently detected species in our survey, followed by $P$. cactorum and members of the

$P$. cryptogea complex. Other species include $P$. cambivora, $P$. cinnamomi, P. citricola, $P$. hedraiandra, P. megasperma, P. multivora, $P$. nicotianae, $P$. niederhauserii, $P$. parvispora, $P$. pini, $P$. plurivora, and $P$. riparia. A few Phytophthora sequences generated from mitochondrial regions could not be assigned to a species. Although this survey was limited to a relatively small number of California native plant nurseries, Phytophthora species were detected from three quarters of them (77\%). In addition to sticky monkeyflower, $P$. tentaculata was detected from seven other hosts, expanding the number of associated hosts. During this survey, $P$. parvispora was detected for the first time in North America from symptomatic crowns and roots of the nonnative Mexican orange blossom (Choisya ternata). Pathogenicity of $P$. parvispora and $P$. nicotianae was confirmed on this host. These findings document the widespread occurrence of Phytophthora spp. in native plant nurseries and highlight the potential risks associated with outplanting infested nursery-grown stock into residential gardens and wildlands.
\end{abstract}

California is the most geographically and climatically diverse state in the United States. Geographically, most of the state lies within the California Floristic Province, one of 36 global hot spots for floristic biodiversity and endemism (Baldwin et al. 2017). California's warm to temperate Mediterranean climate over much of its area and its unique topography and geography have influenced its species richness (Baldwin 2014). More than 25\% of California's estimated $5,280-6,000$ native plant species are endemic to the state and found nowhere else (Baldwin 2014; Baldwin et al. 2012; Jepson Flora Project 2017; Stebbins and Major 1965). In addition to their intrinsic beauty, California native plants are important components of the ecosystem, providing food, shelter, sources of medicines, and other industrial products for people and animals. While California native plants belong to more than 190 families, nearly $40 \%$ of native plant species belong to six major families: Asteraceae, Boraginaceae, Brassicaceae, Fabaceae, Poaceae, and Polygonaceae (Baldwin et al. 2012; Jepson Flora Project 2017).

Phytophthora species are Oomycetes, or eukaryotic water molds currently classified within the Stramenopile lineage. Although their growth habit resembles filamentous fungi, they are more closely related to brown algae and diatoms (Kamoun et al. 2015). Most Phytophthora species produce infectious propagules including zoospores, chlamydospores, and oospores that can be spread short or long distances by soil, rain, water, or movement of infected plant material.

${ }^{\dagger}$ Corresponding author: S. Rooney-Latham; E-mail: slatham@cdfa.ca.gov

Funding: Susan Frankel and the USDA Forest Service obtained funding for some of the service sample testing.

*The $\boldsymbol{e}$-Xtra logo stands for "electronic extra" and indicates that two supplementary figures are published online.

Accepted for publication 2 September 2018.

() 2019 The American Phytopathological Society
In addition to causing important diseases of agricultural crops (Erwin and Ribeiro 1996; Kamoun et al. 2015; Zadoks 2008), Phytophthora species can also cause extensive damage to natural ecosystems. In California, sudden oak death and ramorum blight, caused by Phytophthora ramorum, has resulted in millions of dead tanoak (Notholithocarpus densiflorus [Hook \& Arn.] Manos et al.) and coast live oak (Quercus agrifolia Née), since first detected in 1995 (Rizzo et al. 2002). Genetic analyses indicate that $P$. ramorum was introduced into California's forests by infected nursery stock and spread throughout North America and Europe in the nursery trade (Goss et al. 2011; Grünwald et al. 2012; Mascheretti et al 2008, 2009). Recent models predict that slowing the spread of the pathogen in California forests is no longer possible (Cunniffe et al. 2016).

California's native plant nurseries propagate and supply nursery stock of California native plants to the public and for projects to restore and revegetate wildlands. The goals of these projects include restoring watersheds for the improvement of ground and surface water and mitigating the loss of natural habitat caused by human action. There are nearly 100 native plant nurseries in California that are recognized by the California Native Plant Society (CNPS), with other smaller unrecognized operations. Many of them are unlicensed and not subject to annual nursery inspections for pests and diseases by regulatory officials.

In 2012, Phytophthora tentaculata Kröber \& Marwitz was detected for the first time in the United States in a Monterey County, CA nursery, which produced and sold native and nonnative plants for restoration, commercial, and residential plantings (RooneyLatham and Blomquist 2014). P. tentaculata caused a severe crown and root rot disease of sticky monkeyflower, Diplacus aurantiacus (Curtis) Jeps. (=Mimulus aurantiacus Curtis), a semiwoody perennial native shrub that is widely planted throughout the state in restoration projects. Significant mortality was seen within the block of plants designated for a large restoration project within the county (Rooney-Latham and Blomquist 2014). The plants had been propagated directly from seed, and the source of the pathogen was never determined. P. tentaculata was detected in California again in 2014, on the roots of recently outplanted toyon (Heteromeles arbutifolia 
[Lindl.] M. Roem.) in a restoration site in Alameda County (RooneyLatham et al. 2015b). Subsequent sampling at the site showed that many of the newly planted sticky monkeyflower plants that were grown by the same nursery as the infected toyon, but by a different nursery from the original detection in 2012, were also infected with P. tentaculata (Rooney-Latham et al. 2015b). P. tentaculata remains on the U.S. Regulated Plant Pest List (2018) under the authority of the Plant Protection Act and is considered a quarantined pest for parts of the United States (https://www.aphis.usda.gov/aphis/ourfocus/ planthealth/import-information/rppl).

Phytophthora species are well known and documented in commercial plant nurseries, causing significant economic losses (Erwin and Ribeiro 1996). A 2-year study on the occurrence of foliar Phytophthora species isolated from both native and nonnative hosts in California ornamental nurseries showed that $41 \%$ of symptomatic samples tested positive for Phytophthora spp. by immunoassay (Yakabe et al. 2009). In total, 13 different Phytophthora species were detected in the study, many on hosts with no prior Phytophthora associations. Over a 4-year monitoring period, Parke et al. (2014) found 28 Phytophthora taxa, including hybrids, in four Oregon ornamental nurseries. Studies in other U.S. states have also found Phytophthora infestation in ornamental and commercial landscape nurseries (Bienapfl and Balci 2014; Dart and Chastagner 2007; Donahoo and Lamour 2008; Hoitink and Schmitthenner 1974; Knaus et al. 2015; Patel et al. 2016; Schwingle et al. 2007). A large-scale survey of 732 nurseries in the European Union found more than 49 Phytophthora species in 670 nurseries (Jung et al. 2016). Although Phytophthora spp. are common in ornamental plant nurseries in the United States and Europe, knowledge about the incidence and diversity of Phytophthora species in nurseries that specialize in growing California native plants is limited (Swiecki et al. 2011). The purpose of our survey was to determine whether Phytophthora species are present on native stock in California nurseries using a combination of diagnostic testing procedures, and if present, identify these species using PCR sequencing.

\section{Materials and Methods}

Collection of samples. Between January 2014 and December 2016, 402 samples from plants exhibiting crown or root rot, and occasionally leaf spots and stem cankers (Supplementary Figs. S1 and S2), were submitted from 26 native plant nurseries in 14 California counties. Most of the nurseries were in northern and/or coastal California counties. Some nurseries were sampled multiple times throughout this period of time. Many of the samples were prescreened in the field with Phytophthora ImmunoStrips (Agdia, Elkhart, IN), which in addition to detecting Phytophthora, are known to cross react with Pythium and Phytopythium spp. (MacDonald et al. 1990). California Department of Food and Agriculture (CDFA) plant pathologists collected most of the samples during scheduled visits to nurseries participating in the Best Management Practices (BMP) Program. In addition, some nursery managers and plant brokers submitted samples directly to the lab as service samples, outside of the BMP program. In some cases, the submitter requested testing before selling the material, while in other cases, the broker or receiver (e.g., land manager) of the plants requested testing prior to finalizing the purchase. Initially, testing for P. tentaculata, a federally regulated pathogen, was the primary concern. Soon after the survey began, we began to test for and identify Phytophthora species other than P. tentaculata, when many plants were found infected with other Phytophthora species. In total, 102 different host species, including a few nonnative plant species, were submitted to the CDFA Plant Pest Diagnostics Center (CDFA PPDC) in Sacramento, CA for testing. Samples were packaged in plastic bags and kept at $4{ }^{\circ} \mathrm{C}$ until they were processed. Samples were collected throughout the year. Although hosts that were known to be susceptible to $P$. tentaculata were often targeted for sampling and testing, no attempt was made to control the numbers, locations, or hosts from which samples were collected.

Isolation and ELISA testing. Root and crown tissues were rinsed thoroughly with tap water to remove soil. Samples were blotted dry with paper towels before selecting symptomatic tissue for isolation. Once pieces were selected, they were divided into three sets, each third with an equal amount of symptomatic tissue to be used for ELISA, culture plating, and if necessary, PCR (Fig. 1). The first set of tissue pieces (approximately 4-6 pieces $2 \mathrm{~mm}^{3}$ in size) was directly plated into or onto Phytophthora semiselective CMAPARP media (Jeffers and Martin 1986). CMA-PARP plates were kept in the dark at $20-25^{\circ} \mathrm{C}$ and monitored for hyphal growth for up to 14 days. Suspected Phytophthora colonies were subcultured for purity onto CMA-PARP and used for ITS PCR sequencing and identification. No effort was made to sequence and identify isolates that morphologically resembled Pythium or Phytopythium spp.

The second set of tissue was tested concurrently for Phytophthora spp. by immunoassay. Tissue was ground in a FastPrep Lysing Matrix A tube (MP Biomedical, Solon, OH) with $1 \mathrm{ml}$ of GEB2 buffer (Agdia, Elkhart, IN) in a Fast Prep machine (MP Biomedical, Solon, $\mathrm{OH})$. Aliquots of the grindate $(100 \mu \mathrm{l})$ were tested in duplicate using a Phytophthora species-specific ELISA kit (Cat no. SRA 92601; Agdia, Elkhart, IN) according to the manufacturer's instructions. If no Phytophthora culture was obtained but the $\mathrm{OD}_{405}$ reading of the ELISA was at least two times background level (approximately 0.2 or greater), DNA was extracted and tested for Phytophthora using PCR from the third set of tissue, which had been held at $4^{\circ} \mathrm{C}$.

PCR identification. Phytophthora spp. isolates. DNA from Phytophthora cultures obtained from direct isolation was extracted from 5- to 10-day-old colonies. For each isolate, a $2 \mathrm{~mm}^{3}$ agar piece was excised from colonies and DNA was extracted following the Qiagen DNeasy Plant Mini Kit protocol (Qiagen, Valencia, CA). Between January 2014 and July 2016, rDNA of the internal transcribed spacer (ITS) region, including the $5.8 \mathrm{~S}$ gene and portions of $18 \mathrm{~S}$ and $28 \mathrm{~S}$ genes were amplified with primers ITS1 and ITS4 (White et al. 1990) using a Bio-Rad C1000 Touch Thermal Cycler (Bio-Rad Laboratories, Hercules, CA). PCR reactions were performed using the following parameters: an initial denaturation for $5 \mathrm{~min}$ at $94^{\circ} \mathrm{C}$, followed by 34 cycles of $1 \mathrm{~min}$ at $94^{\circ} \mathrm{C}, 1 \mathrm{~min}$ at $50^{\circ} \mathrm{C}$, and $1 \mathrm{~min}$ at $72^{\circ} \mathrm{C}$. A final extension of $72^{\circ} \mathrm{C}$ was done for $5 \mathrm{~min}$. In 2016, rDNA of the ITS region was amplified and sequenced using primers PHY.OO18S.F and PHY.OO.28S.R from G. Abad (personal communication). PCR reactions were mixed in a total volume of $25 \mu \mathrm{l}$ containing $1 \times$ Takara Premix Ex Taq DNA Polymerase (Takara Bio Inc., Otsu, Japan), $400 \mathrm{nM}$ of forward and reverse primers, and $2 \mu$ l of DNA template. Each sample was tested undiluted and at a 1:100 dilution. Molecular grade water was added to obtain a final volume of $25 \mu \mathrm{l}$. PCR reactions included an initial denaturation for $1.5 \mathrm{~min}$ at $95^{\circ} \mathrm{C}$, followed by 35 cycles of $55 \mathrm{~s}$ at $94^{\circ} \mathrm{C}, 30 \mathrm{~s}$ at $64^{\circ} \mathrm{C}$, and $1 \mathrm{~min}$ at $72^{\circ} \mathrm{C}$, with a final extension of $72^{\circ} \mathrm{C}$ for $10 \mathrm{~min}$.

All products were purified using the Qiagen QIAquick PCR Purification Kit (Qiagen, Valencia, CA) and directly sequenced by GeneWiz (South Plainfield, NJ) using the amplification primers. Complimentary forward and reverse DNA strands were aligned with the software program Sequencher 5.3 (Gene Codes Corp., Inc., Ann Arbor, MI). Consensus sequences were compared with those from voucher specimens deposited to the Phytophthoradb website (www.phytophthoradb.org, accessed Jan. 2014-Dec. 2016). Taxa were assigned to isolates with sequence identities above 99\% (Jung et al. 2017; Junker et al. 2016). Identification of some samples could not be resolved using the single ITS locus, and these samples were assigned to a Phytophthora species complex if appropriate.

Directly from root tissue. Root samples which tested positive by ELISA with an $\mathrm{OD}_{405}$ of at least two times background, but from which no Phytophthora species grew in culture, were also tested using Phytophthora species-specific PCR primers. Between January 2014 and July 2016, $0.075 \mathrm{~g}$ of washed root tissue from each sample was extracted using the Qiagen DNeasy Plant Mini Kit as described above, and tested for Phytophthora spp. using a real-time PCR (qPCR) assay specific for Phytophthora. Two different mitochondrial loci, trnM-trnP-trnM (trnM) and atp9-nad9 (nad9) (Bilodeau et al. 2014), were targeted to identify Phytophthora spp. present in DNA root extracts. The nad9 locus was preferentially used for 
sequencing and species identification. For samples from which a Phytophthora species could not clearly be identified using the nad9 region sequences, the trnM region was amplified and sequenced.

The Cepheid Smart Cycler II thermal cycler (Cepheid, Sunnyvale, CA) was used for all qPCR reactions amplifying mitochondrial DNA. DNA was amplified from the nad9 region using $1 \times$ RealMasterMix without Rox (5Prime Inc., Gaithersburg, MD), $0.5 \mu \mathrm{M}$ PhyGATP9/R6, $6.0 \mathrm{mM} \mathrm{MgCl} 2,0.05 \mu \mathrm{M}$ ATP9-PhyG2 probeR, labeled with FAM fluorophore and $2 \mu$ of DNA template, in a total volume of $25 \mu$ l (Bilodeau et al. 2014). Each sample was tested undiluted and at a 1:10 dilution. PCR reaction parameters included an initial denaturation for $120 \mathrm{~s}$ at $95^{\circ} \mathrm{C}$, followed by 50 cycles of $95^{\circ} \mathrm{C}$ for $15 \mathrm{~s}$ and $57^{\circ} \mathrm{C}$ for $90 \mathrm{~s}$. PCR reactions amplifying the trnM region included $1 \times$ RealMasterMix without Rox, $0.5 \mu \mathrm{M}$ PhyG-F2/Rb, $6.0 \mathrm{mM} \mathrm{MgCl}$, and $0.1 \mu \mathrm{M}$ TrnM PhyG probe2, labeled with FAM fluorophore, in a total volume of $25 \mu \mathrm{l}$ (Bilodeau et al. 2014). Initial denaturation was at $95^{\circ} \mathrm{C}$ for $120 \mathrm{~s}$, followed by 50 cycles of $95^{\circ} \mathrm{C}$ for $15 \mathrm{~s}$ and $62^{\circ} \mathrm{C}$ for $90 \mathrm{~s}$. Primers FMP12b and FMP13b $(0.0325 \mu \mathrm{M})$ and probe Plant CAL-Red $(0.026 \mu \mathrm{M})$ were used as an internal control to amplify plant DNA (Bilodeau et al. 2014). Samples with a valid internal control TxRed Ct value were determined to be Phytophthora positive if they had FAM Ct values between 15.00 and 38.00, and negative if they had values of 0 . An additional qPCR was performed on the positive samples, without the internal plant primers and probes, for species identification. The resulting amplicon, of either $340 \mathrm{bp}$ (nad9) or 206 bp (trnM), was purified using the QIAquick PCR Purification Kit, sequenced by GeneWiz, and compared with a bank of known Phytophthora mitochondrial sequences.

DNA from samples with an $\mathrm{OD}_{405}$ of at least 8 times background, but that did not amplify a Phytophthora spp. by qPCR were amplified and sequenced using PCR primers DC6 and ITS4 (Cooke et al. 2000; White et al. 1990) to confirm that a Phytophthora was not present. PCR products were purified and sequenced as described above and consensus sequences were compared with those deposited online on The Phytophthora Database.

In August 2016, a conventional PCR using oomycete-specific primers PHY.OO.18S.F and PHYOO.28S.R (G. Abad, personal communication) was used in place of the real-time PCR for identification of Phytophthora sp. from root extracts. DNA was extracted as previously described for fungal cultures using the Qiagen DNeasy Plant Mini Kit protocol except instead of extracting from fungal hyphae in agar plugs, DNA was extracted from approximately $0.075 \mathrm{~g}$ of root tissue. PCR reactions, amplicon purification, and sequencing were performed as described above using primer pairs PHY.OO.18S. F and PHYOO.28S.R on Phytophthora cultures.

Pathogenicity tests of new Phytophthora host associations. Pathogenicity of $P$. nicotianae and $P$. parvispora was tested on

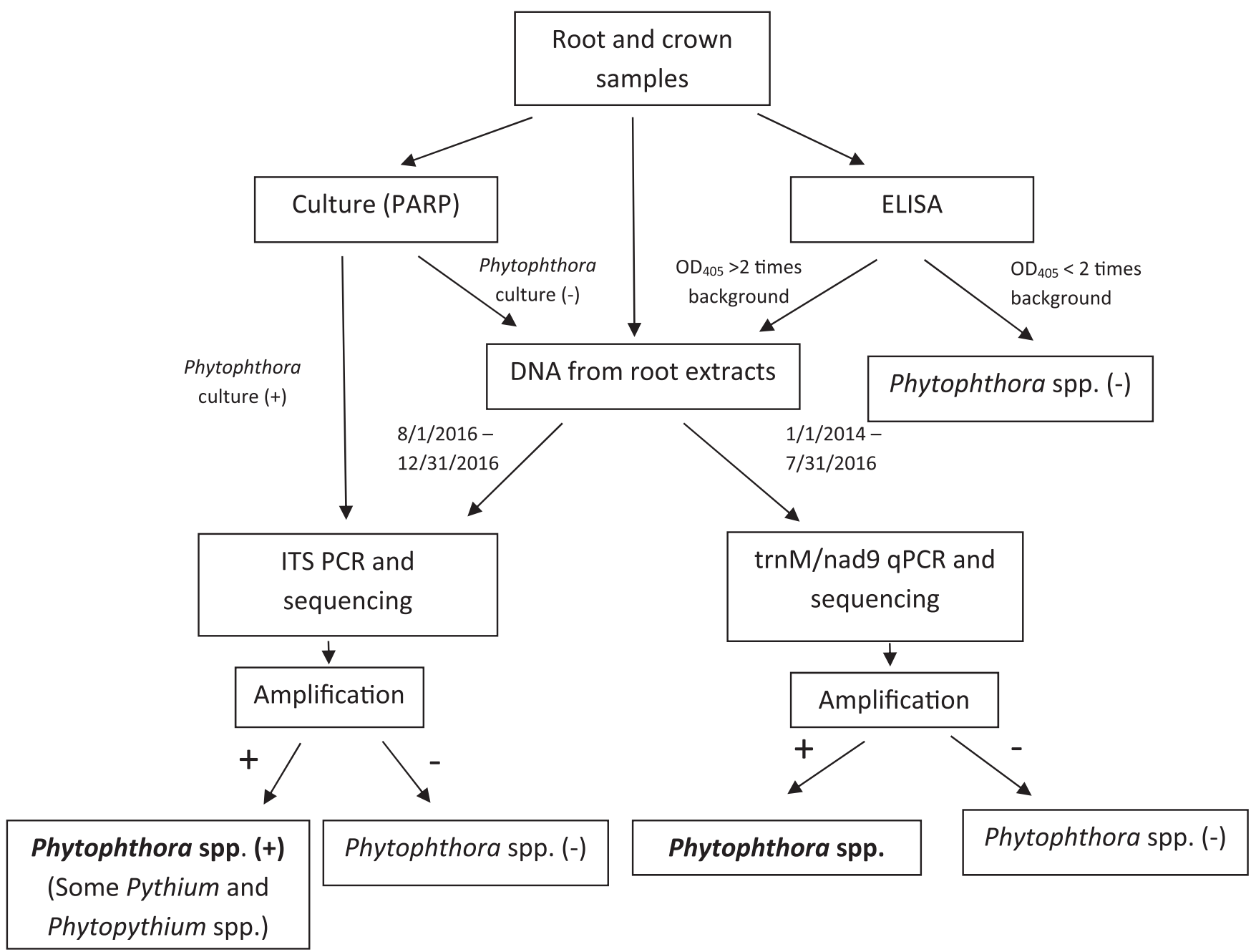

Fig. 1. Flow chart for testing of plant samples for Phytophthora spp. at the California Department of Food and Agriculture Laboratory. Ten 2-mm ${ }^{2}$ samples from root and crown tissue were selected and divided. Five of the pieces were placed on PARP semiselective media and the other five were tested by an Agdia Phytophthora enzyme-linked immunosorbent assay (ELISA). If the optical density (OD) at $405 \mathrm{~nm}$ from ELISA assay measured more than twice the background, but no Phytophthora was obtained in culture, $0.075 \mathrm{~g}$ of root and crown tissue was tested for Phytophthora by polymerase chain reaction (PCR). Between January 2014 and July 2016, DNA from root extracts was tested by real-time PCR (qPCR) using primers that target two different mitochondrial loci of Phytophthora, trnM-trnP-trnM (trnM) and atp9-nad9 (nad9). In August 2016, an oomycete-specific conventional PCR targeting rDNA of the internal transcribed spacer (ITS) region, including the $5.8 \mathrm{~S}$ gene and portions of $18 \mathrm{~S}$ and $28 \mathrm{~S}$ genes was used. If a Phytophthora culture was obtained during the original plating process, DNA was extracted directly from the culture and PCR of the ITS region was done, regardless of the ELISA OD value. All PCR amplicons were sequenced and compared to known reference strains for Phytophthora confirmation and species identification. 
Mexican orange blossom (Choisya ternata 'Sundance') by inoculating plants grown in $15.24-\mathrm{cm}$-diameter pots. To ensure plants were healthy before inoculation, they were kept in isolation in a shade house for 12 weeks and monitored for any symptoms of root and crown disease. After this period, three plants were inoculated with $P$. nicotianae and three were inoculated with $P$. parvispora. One $3-$ $\mathrm{mm}$ colonized agar plug taken from cultures grown on V8 agar for 7 days was placed into a wedge-shaped wound made into the vascular tissue of the crown, near the soil line, and secured with Parafilm. Plugs of uncolonized V8 agar were placed onto wounds of two control plants. Plants were placed in a $23^{\circ} \mathrm{C}$ growth chamber with a 12 -h photoperiod. Vascular discoloration was measured after 18 days for the plants inoculated with $P$. nicotianae and after 42 days for those inoculated with $P$. parvispora. The vasculature near the inoculation point was assessed on one control plant after 18 days and the other after 42 days. Isolations from symptomatic tissue were made on CMA-PARP, and cultures were monitored regularly for growth of Phytophthora. DNA from suspected Phytophthora colonies was extracted, and confirmation of species was made by ITS PCR sequencing as described above. The experiment was performed once.

\section{Results}

Isolation and ELISA testing. In this study, 370 (92\%) of the 402 total samples tested had an immunoassay $\mathrm{OD}_{405}$ reading of 0.2 (average of twice the background) or greater and required further testing. Of these 370 samples, 195 had $\mathrm{OD}_{405}$ readings at least 8 times background (0.8), and $149(40 \%)$ tested positive for Phytophthora sp. by culture or PCR. Phytophthora sp. was detected from only $3(1.7 \%)$ of the 175 samples with $\mathrm{OD}_{405}$ readings between 0.2 and 0.79 .

Pythium and Phytopythium, two related oomycete genera that are known to cross-react with the Phytophthora immunoassay, were confirmed by PCR from some of the samples that did not yield a Phytophthora sp. Of the samples with immunoassay $\mathrm{OD}_{405}$ readings between 0.2 and 0.8, Pythium irregulare, Phytopythium litorale, and Phytopythium helicoides were repeatedly confirmed from root extracts by PCR sequencing using primers DC6/ITS4. Additional samples yielded Pythium spp. sequences that could not be identified, either because infections were mixed or sequence queries found no matches in GenBank. Twelve out of the 44 samples with an $\mathrm{OD}_{405}$ greater than 0.8 , that did not yield a Phytophthora in culture or by PCR, were Pythium dissotocum and Pythium catenulatum. The average $\mathrm{OD}_{405}$ readings were 2.2 for Pythium dissotocum and 2.9 for Pythium catenulatum.

PCR identification. A Phytophthora sp. was cultured from 92 (61.7\%) of the 149 samples that were infected with a Phytophthora species. Phytophthora was confirmed from the remaining 58 samples by direct PCR from DNA extracted from plant tissue. Two Phytophthora species were cultured from one of the samples. Although no effort was made to sequence and identify isolates that morphologically resembled Pythium or Phytopythium spp., some of the sequences matched species of these genera (data not shown).

Phytophthora species in native plant nurseries. Of the 14 California counties in which samples were collected, Phytophthora was detected from 11 of them (Butte, Contra Costa, Monterey, Orange, Placer, Sacramento, San Diego, San Francisco, San Mateo, Santa Clara, and Santa Cruz). One or more Phytophthora species was detected from 20 of the $26(77 \%)$ nurseries that were surveyed. Phytophthora was confirmed from 149 of the 402 total samples $(37.3 \%)$, including one sample that was infected with two different species.

The most frequently detected Phytophthora species in our survey was $P$. tentaculata (41), followed by P. cactorum (34), species in the $P$. cryptogea complex (20), P. nicotianae (11), P. niederhauserii (8), $P$. hedraiandra (8), P. cambivora (7), and P. multivora (5). Species with fewer than 5 detections included $P$. cinnamomi, $P$. citricola, $P$. megasperma, $P$. parvispora, $P$. pini, $P$. plurivora, and $P$. riparia (Table 1). Detections of $P$. tentaculata accounted for $41(27 \%)$ of the total Phytophthora detections. Of the samples determined to be positive for $P$. tentaculata, it was successfully cultured from $66 \%$ while the remaining $34 \%$ were confirmed by PCR amplification and sequencing from DNA extracted from root tissue. The rate of success obtaining $P$. tentaculata in culture was similar to our rate of other Phytophthora spp. in the study. In total, P. tentaculata was detected from seven different hosts. In addition to Diplacus aurantiacus (Phrymaceae), many species in the Asteraceae and Lamiaceae were infected with $P$. tentaculata. Species of Artemisia L. may be especially susceptible to $P$. tentaculata; it was detected from eight different samples, including all four of the Artemisia taxa that were submitted (Table 2).

$P$. cactorum was the second most frequently detected species, and accounted for $23 \%$ of the overall Phytophthora detections. Most of the detections were from plant species with known associations of P. cactorum, including coffeeberry (Frangula californica [Eschsch.] A. Gray), toyon (Heteromeles arbutifolia [Lindl.] M. Roem), blueblossom (Ceanothus thyrsiflorus Eschsch.), Pacific madrone (Arbutus menziesii Pursh.), and wild strawberry (Fragaria vesca L.) (Farr and Rossman 2017). Detections from plant species not known to be hosts of $P$. cactorum included sticky monkeyflower (Diplacus aurantiacus [Curtis] Jeps.), Monterey manzanita (Arctostaphylos montereyensis Hoover), dune manzanita (Arctostaphylos pumila Nutt.), Monterey ceanothus (Ceanothus rigidus Nutt.), chamise (Adenostoma fasciculatum Hook. \& Arn.), mountain mahogany (Cercocarpus betuloides Nutt.), sticky cinquefoil (Drymocallis glandulosa [Lindl.] Rydb.), California wild rose (Rosa californica Cham. \& Schltdl.), and common verbena (Verbena lasiostachys Link.) Isolates matched the vouchered specimens with 99-100\% similarity. Samples infected with Phytophthora species in the P. cryptogea complex, which included close matches to $P$. kelmania, $P$. cryptogea, and $P$. drechsleri, accounted for the third most detections, while P. nicotianae was the fourth most detected species (Table 1).

Of the 102 different host species that were tested, at least one Phytophthora species was detected from 51 of them (Table 2). Most of the hosts were members of the plant families Asteraceae, Ericaceae, Phrymaceae, Rhamnaceae, and Rosaceae. Sticky monkeyflower (Diplacus aurantiacus), including its various cultivars, was the only detection in the Phrymaceae (Table 2). Thirty of the 36 Phytophthora detections on sticky monkeyflower and its cultivars were $P$. tentaculata. Other species detected on sticky monkeyflower were $P$. cactorum, $P$. cryptogea, and $P$. nicotianae (Table 2 ). Prior to this study, no Phytophthora associations other than P. tentaculata were known on sticky monkeyflower (Farr and Rossman 2017).

The number of samples collected in each nursery and the number of Phytophthora species detected in those nurseries varied widely. Ten of the 26 nurseries that were surveyed provided $80 \%$ of the total

Table 1. Frequency of Phytophthora spp. detections in California native plant nurseries by either culture or PCR

\begin{tabular}{lccc}
\hline & \multicolumn{3}{c}{ Phytophthora detections } \\
\cline { 2 - 4 } & Culture & PCR & Total \\
\hline P. cactorum and c.f. cactorum & $\mathbf{1 9}$ & $\mathbf{1 5}$ & $\mathbf{3 4}$ \\
P. cambivora & 4 & 3 & 7 \\
P. cinnamomi & 1 & 1 & 2 \\
P. citricola & 2 & 0 & 2 \\
P. cryptogea complex & $\mathbf{1 2}$ & $\mathbf{8}$ & $\mathbf{2 0}$ \\
P. hedraiandra & 4 & 4 & 8 \\
P. megasperma & 0 & 1 & 1 \\
P. multivora & 3 & 2 & 5 \\
P. nicotianae & 9 & 2 & 11 \\
P. niederhauserii & 8 & 0 & 8 \\
P. parvispora & 1 & 0 & 1 \\
P. pini & 1 & 1 & 2 \\
P. plurivora & 1 & 1 & 2 \\
P. riparia & 0 & 1 & 1 \\
P. tentaculata & $\mathbf{2 7}$ & $\mathbf{1 4}$ & $\mathbf{4 1}$ \\
Other Phytophthora sp. or Unresolved & 0 & 5 & 5 \\
Phytophthora spp. & & & \\
Total & 92 & 58 & 150 \\
& & $(61.3 \%)$ & $(38.7 \%)$ \\
\hline
\end{tabular}


samples, while a few nurseries provided very few. One nursery submitted 92 samples for Phytophthora testing, and we detected Phytophthora from $59 \%$ of these samples. Thirty-four different plant species and cultivar selections at this site tested positive for one or more Phytophthora species, and 12 of the 15 Phytophthora species that were detected in this study were found at this infested nursery.

Pathogenicity tests of two new Phytophthora host associations. The detection of Phytophthora parvispora on Choisya ternata in September 2016 was the first detection of this species in North America. Original symptoms on submitted plants included yellow foliage, stunted growth, and brown necrotic roots and root collars. Pathogenicity experiments were performed on separate healthy $C$. ternata 'Sundance' plants with both $P$. parvispora and $P$. nicotianae to complete Koch's postulates. After 14 days, the foliage of $C$. ternata plants inoculated with $P$. nicotianae began to wilt, and dark brown, sunken cankers were seen at the point of inoculation. Plants inoculated with $P$. parvispora began to wilt after 32 days, and brown lesions were seen at the inoculation points. After 18 days, stem lesions averaged $70 \mathrm{~mm}$ for plants inoculated with $P$. nicotianae, while they averaged $35 \mathrm{~mm}$ after 42 days for plants inoculated with $P$. parvispora. No vascular discoloration or wilting was observed on the control plants. $P$. parvispora and $P$. nicotianae were isolated from stem cankers of all inoculated plants, while no Phytophthora spp. grew from the control plants. Species confirmation was made by ITS PCR amplification and sequencing of the ITS region from recovered isolates. Sequences of both species matched sequences of vouchered specimens of $P$. parvispora and $P$. nicotianae with $100 \%$ similarity and were deposited into GenBank (MH375345 P. nicotianae; MH375344 P. parvispora).

\section{Discussion}

Phytophthora species appear to be widespread and common in native plant nurseries in California. Results from this survey of native plant nurseries over a period of 35 months confirmed the presence of Phytophthora spp. in 20 out of the 26. A Phytophthora species was detected by culture or PCR from approximately $37 \%$ of the total samples collected. Confirmations were made with positive cultures from $23 \%$ of the total samples collected and by direct PCR from $15 \%$ of the samples. Overall, ELISA testing of roots and crowns was a useful prescreen for Phytophthora, with Phytophthora confirmed in more than $75 \%$ of the samples with $\mathrm{OD}_{405}$ readings of 0.8 or greater. The remaining $25 \%$ were likely Pythium and Phytopythium spp. that are known to cross react with the immunoassay. This was evident in our study, especially with samples with $\mathrm{OD}_{405}$ values between 2 and 8 times background. Two species of Pythium, Py. dissotocum and Py. catenulatum, cross-reacted strongly with $\mathrm{OD}_{405}$ readings near 20 times background, highlighting the potential for false positives if the immunoassay alone is used for diagnosis. Although both $P$ y. dissotocum and Py. catenulatum can cause dampingoff and root rots on plant hosts in other parts of the world (Farr and Rossman 2017), and Py. dissotocum was recently found to be a pathogen on hydroponically grown lettuce (McGehee and Raudales

Table 2. Frequency of Phytophthora spp. detections by host during a 2014-2016 survey of California native plant nurseries ${ }^{\mathrm{a}}$

\begin{tabular}{|c|c|c|c|c|c|c|c|c|c|c|c|c|c|c|c|c|c|}
\hline & P. cac & P. cam & P. cin & P. cit & P.cry & P. hed & P. meg & P. mul & P. nic & P. nie & P.par & P. pin & P. plu & P. rip & P. ten & P. spp. & Total \\
\hline \multicolumn{18}{|l|}{ Agavaceae } \\
\hline Hesperoyucca whipplei & & & & & 2 & & & & & & & & & & & & 2 \\
\hline \multicolumn{18}{|l|}{ Asteraceae } \\
\hline Artemisia californica & & & & & & & 1 & & & & & & & & 2 & & 3 \\
\hline Artemisia dracunculus & & & & & & & & & & & & & & & 2 & & 2 \\
\hline Artemisia douglasiana & & & & & & & & & & & & & & & 2 & & 2 \\
\hline Artemisia palmeri & & & & & & & & & & & & & & & 1 & & 1 \\
\hline Artemisia 'Powis Castle' & & & & & 1 & & & & & & & & & & & & 1 \\
\hline Baccharis pilularis & & & & & & & & 1 & & & & & & & & & 1 \\
\hline Ericameria ericoides & & & & & 1 & & & & & & & & & & & & 1 \\
\hline Eriophyllum confertiflorum & & & & & 1 & & & & & & & & & & & & 1 \\
\hline Lessingia sp. & & & & & & & & & & & & & & & & 1 & 1 \\
\hline \multicolumn{18}{|l|}{ Betulaceae } \\
\hline Corylus cornuta & & & & & & & & & & & & & & & & 1 & 1 \\
\hline \multicolumn{18}{|l|}{ Calycanthaceae } \\
\hline Calycanthus occidentalis & & & & & & & & & 1 & & & & & & & & 1 \\
\hline \multicolumn{18}{|l|}{ Caprifoliaceae } \\
\hline Lonicera hispidula & & & & & & & & & & & & 1 & & & & & 1 \\
\hline \multicolumn{18}{|l|}{ Cistaceae } \\
\hline Crocanthemum scoparium & & & & & & & & & & 2 & & & & & & & 2 \\
\hline \multicolumn{18}{|l|}{ Ericaceae } \\
\hline Arbutus menziesii & 3 & & & & & & & & & & & & & & & & 3 \\
\hline Arctostaphylos glandulosa & & & & & 1 & & & & 1 & & & & & & & & 2 \\
\hline $\begin{array}{l}\text { Arctostaphylos } \\
\text { montereyensis }\end{array}$ & 1 & 3 & & & & & & 1 & & & & & & & & & 5 \\
\hline Arctostaphylos pumila & 1 & 2 & & & & 8 & & 1 & & & & & & & & & 12 \\
\hline Rhododendron occidentale & & & & & & & & & & & & & & & & 1 & 1 \\
\hline \multicolumn{18}{|l|}{ Fagaceae } \\
\hline Notholithocarpus densiflorus & & & 1 & & & & & & & & & & & & & & 1 \\
\hline Quercus agrifolia & & & & & 1 & & & & & & & & & & & & 1 \\
\hline \multicolumn{18}{|l|}{ Grossulariaceae } \\
\hline Ribes divaricatum & & & & & 1 & & & & & & & & & & & & 1 \\
\hline \multicolumn{18}{|l|}{ Lauraceae } \\
\hline \multirow[t]{2}{*}{ Umbellularia californica } & & & 1 & & & & & & & & & & & 1 & & & 2 \\
\hline & & & & & & & & & & & & & & \multicolumn{4}{|c|}{ (Continued on next page) } \\
\hline
\end{tabular}

${ }^{a}$ Key to Phytophthora species: P. cac - Phytophthora cactorum/P. cf. cactorum, P. cam - Phytophthora cambivora, P. cin - Phytophthora cinnamomi, P. cit - Phytophthora citricola, P. cry - Phytophthora cryptogea complex, P. hed - Phytophthora hedraiandra, P. meg - Phytophthora megasperma. $\boldsymbol{P}$. $\mathbf{m u l}$ - Phytophthora multivora, $\boldsymbol{P}$. nic - Phytophthora nicotianae, $\boldsymbol{P}$. nie - Phytophthora niederhauserii, $\boldsymbol{P}$. par - Phytophthora parvispora, $\boldsymbol{P}$. pin Phytophthora pini, P. plu - Phytophthora plurivora, P. rip - Phytophthora riparia, P. ten - Phytophthora tentaculata, P. spp. - other Phytophthora or unable to speciate. 
2018), their pathogenicity on California natives is not known and was not investigated in this work.

Although the host sampling in our study was somewhat biased toward Diplacus sp., other potentially new hosts associations of $P$. tentaculata were also identified. Prior to this work, $P$. tentaculata had primarily been detected on common ornamental woody perennials and a limited number of agricultural hosts in Europe and China, including Apium L., Aucklandia Falc., Chrysanthemum L., Cichorium L., Gazania Gaertn., Origanum L., Santolina L., and Verbena L. spp. (Farr and Rossman 2017; Rooney-Latham et al. 2015a). To date, in the United States, $P$. tentaculata has been detected only on California native species, not on agricultural hosts. Our study confirmed that California natives are associated with other Phytophthora species (Table 2). The detection of $P$. parvispora in this survey and subsequent completion of Koch's postulates on C. ternata confirmed the presence of a new pathogenic Phytophthora species in the United States. Genetically, $P$. parvispora is very closely related to $P$. cinna$m o m i$ and was originally considered a variety of $P$. cinnamomi when it was first detected causing stem rot of Beaucarnea spp. in Germany (Kröber and Marwitz 1993). It was also recently found to cause severe dieback including root and collar rot on Arbutus unedo L. in Italy (Scanu et al. 2014). In our study, P. parvispora was found with $P$. nicotianae causing crown rot of a nonnative host, $C$. ternata. Although pathogenicity experiments confirmed that $P$. nicotianae is more virulent on $C$. ternata, $P$. parvispora was also able to induce wilting and stem lesions. The host range of $P$. parvispora is still unknown, but if it has a similar host range (more than 3,000 species) as
P. cinnamomi (Hardham 2005), there is cause for concern. P. parvispora and $P$. tentaculata remain on the U.S. Regulated Plant Pest List (2018) and are considered quarantined pests in parts of the United States (https://www.aphis.usda.gov/aphis/ourfocus/planthealth/ import-information/rppl).

Although relatively few Phytophthora associations with native species have been documented, the susceptibility of California natives to Phytophthora is not surprising. The climate of most of California, including the coastal areas, Central Valley, and Sierra Nevada foothills, is regarded as Mediterranean (moderately wet winters and hot to warm, dry summers) (Köppen 1884; Rubel and Kottek 2011). Whether pathogenic Phytophthora species are native soil inhabitants in California wildlands is unknown. However, native plants often exhibit little to no resistance to nonnative pathogens like $P$. tentaculata. Unlike plants in the wildlands, container grown nursery stock requires summer irrigation for survival. If a Phytophthora $\mathrm{sp}$. is present in the roots of a few plants in a nursery, watering in the warmer months, when many Phytophthora species are in active growth, can cause the release of zoospores into water films out of the pots and into adjacent susceptible host plants, spreading the pathogen.

Although culturing was a successful method for detecting Phytophthora in our study, direct PCR amplification and sequencing from infected roots was a useful tool when a culture could not be obtained from infected plants. Prior to August 2016, we used two different real-time PCR assays that target different loci of Phytophthora for our testing (Bilodeau et al. 2014). Both trnM and nad9 are highly

Table 2. (Continued from previous page)

P. cac P.cam P. cin P. cit P. cry P. hed P. meg P. mul P. nic P. nie P.par P.pin P.plu P. rip P.ten P. spp. Total

\begin{tabular}{|c|c|c|c|c|c|c|c|c|c|c|c|c|c|c|c|c|c|}
\hline \multicolumn{18}{|l|}{ Lamiaceae } \\
\hline Salvia leucophylla & & & & & 2 & & & & & & & & & & & & 2 \\
\hline Salvia mellifera & & & & & 1 & & & & 1 & & & & & & & & 2 \\
\hline Salvia sp. & & & & & & & & & & 1 & & & & & 1 & & 2 \\
\hline Monardella villosa & & & & & & & & & & & & & & & 2 & & 2 \\
\hline \multicolumn{18}{|l|}{ Phrymaceae } \\
\hline Diplacus aurantiacus & 1 & & & & 1 & & & & 3 & & & & & & 22 & & 27 \\
\hline Diplacus aurantiacus cvs. & & & & & 1 & & & & & & & & & & 8 & & 9 \\
\hline \multicolumn{18}{|l|}{ Plantaginaceae } \\
\hline Penstemon centranthifolius & & & & & 2 & & & & & & & & & & & & 2 \\
\hline \multicolumn{18}{|l|}{ Platanaceae } \\
\hline Platanus racemosa & & & & & 1 & & & & & & & & & & & & 1 \\
\hline \multicolumn{18}{|l|}{ Polygonaceae } \\
\hline Eriogonum latifolium & & & & & 1 & & & & & & & & & & & & 1 \\
\hline \multicolumn{18}{|l|}{ Rhamnaceae } \\
\hline Ceanothus 'Julia Phelps' & & & & & & & & & 1 & & & & & & & & $\mathbf{1}$ \\
\hline Ceanothus cuneatus & & & & & & & & & 1 & & & & & & 1 & & 2 \\
\hline Ceanothus rigidus & 2 & & & & & & & & & & & & & & & & 2 \\
\hline Ceanothus thyrsiflorus & 1 & & & & & & & 1 & 1 & & & & & & & & $\mathbf{3}$ \\
\hline Frangula californica & 6 & & & 2 & & & & 1 & & 3 & & & & & & 1 & 13 \\
\hline Ceanothus sp. & 2 & & & & & & & & & & & & & & & & 2 \\
\hline \multicolumn{18}{|l|}{ Rosaceae } \\
\hline Adenostoma fasciculatum & 1 & & & & & & & & & 2 & & 1 & & & & & 4 \\
\hline Cercocarpus betuloides & 1 & 1 & & & & & & & & & & & & & & & 2 \\
\hline Drymocallis glandulosa & 1 & & & & 2 & & & & & & & & & & & & 3 \\
\hline Fragaria vesca & 1 & & & & & & & & & & & & & & & & $\mathbf{1}$ \\
\hline Heteromeles arbutifolia & 9 & & & & 1 & & & & & & & & & & & & 10 \\
\hline Prunus ilicifolia & & 1 & & & & & & & & & & & & & & & 1 \\
\hline Rosa californica & 3 & & & & & & & & & & & & & & & & 3 \\
\hline \multicolumn{18}{|l|}{ Rutaceae } \\
\hline Choisya ternata & & & & & & & & & 1 & & 1 & & & & & & 2 \\
\hline \multicolumn{18}{|l|}{ Salicaceae } \\
\hline Salix laevigata & & & & & & & & & & & & & 1 & & & & 1 \\
\hline \multicolumn{18}{|l|}{ Sapindaceae } \\
\hline Acer macrophyllum & & & & & & & & & & & & & 1 & & & & 1 \\
\hline Aesculus californica & & & & & & & & & & & & & & & & 1 & $\mathbf{1}$ \\
\hline \multicolumn{18}{|l|}{ Scrophulariaceae } \\
\hline Scrophularia californica & & & & & & & & & 1 & & & & & & & & 1 \\
\hline \multicolumn{18}{|l|}{ Verbenaceae } \\
\hline Verbena lasiostachys & 1 & & & & & & & & & & & & & & & & 1 \\
\hline Total & 34 & 7 & 2 & 2 & 20 & 8 & 1 & 5 & 11 & 8 & 1 & 2 & 2 & 1 & 41 & 5 & 150 \\
\hline
\end{tabular}


conserved in the gene order of Phytophthora and do not amplify Pythium or Phytopythium spp. Of the two loci, nad9 was preferentially used since it is more variable in closely related Phytophthora species, including the loci of the closely related $P$. cactorum and $P$. hedraiandra. However, a major drawback we found with the nad9 primers was that they did not always amplify California isolates of $P$. tentaculata in infected roots, resulting in some false negatives, if used alone. We were able to confirm these plants were infected with $P$. tentaculata by amplifying and sequencing either the trnM or ITS region. We suspect the inability of these primers to amplify all isolates may be due to single nucleotide polymorphisms (SNPs) in the California population of $P$. tentaculata, although it was not confirmed in this study.

Overall, the major advantage to both the nad9 and the trnM PCR assays was their specificity to Phytophthora and their inability to cross-react with Pythium and Phytopythium spp. However, the need to perform additional PCR tests that target other genes when the nad9 PCR failed was laborious. Furthermore, we found it difficult to resolve species in complexes like $P$. cryptogea and $P$. cactorum with the limited databases available for these two loci, a problem which has been previously documented for other databases (Kang et al. 2010). Hybrid species may also not be represented in more limited databases and may explain our inability to resolve all our PCR Phytophthora detections. Since mitochondrial regions are inherited uniparentally, identification of hybrid species is not always possible without confirmation using an additional nuclear region, such as the ITS.

Since ITS sequences are overall more readily available on multiple sequence databases and for newly described taxa, we began using a conventional PCR protocol with the oomycete primers (PHYOO) in August 2016. Although these primers cross-react with Pythium and Phytopythium species, they consistently amplify an ITS product that can be sequenced easily and compared with sequences in larger and more diverse database than those available for mitochondrial based sequences. For this reason, most Phytophthora surveys over the last 15 years have targeted the ITS region for species identification (Jung et al. 2016; Yakabe et al. 2009). However, the multicopy nature of the ITS region makes it difficult to recognize potential hybrid species (Jung et al. 2017) if used alone. Many previous Phytophthora surveys have focused only on cultural methods. Our multitool approach using an immunoassay prescreen, culturing, and PCR amplification likely resulted in more Phytophthora detections. Without the use of PCR, we would have missed nearly $40 \%$ of the Phytophthora infections in our survey.

The detection of $P$. tentaculata from containerized native plant material that had been planted out into the wildlands raised significant concerns among California's native plant groups and regulatory agencies (Frankel et al. 2015). Invasive Phytophthora species can cause severe and long-lasting damage to native plant communities. In addition to $P$. ramorum, introductions of $P$. cinnamomi have caused significant mortality throughout the world. In California, $P$. cinnamomi has threatened multiple species of already endangered manzanita, including Arctostaphylos pallida Eastw. and A. myrtifolia Parry (Swiecki et al. 2011). P. cinnamomi has also caused widespread damage in Europe and Australia, where it is continuing to threaten some of the world's most species-rich and complex ecosystems (Brasier 2008). The detection of P. cinnamomi, as well as at least 14 other Phytophthora species on native plant nursery stock in our study, is concerning.

In addition to fears about the movement of infected plant material into native habitats, concerns over the outplanting of asymptomatic but infected plant material have also been raised (Dart and Chastagner 2007; Migliorini et al. 2015). In response to this concern, there has been an increased interest in using biological baits such as green pears to screen roots, media, and leachate in native plant nurseries for the presence of any Phytophthora. While this is a more exhaustive detection method and allows for the nondestructive sampling of larger lots of plants, this technique was not used in our survey. Since CDFA is a regulatory agency and our positive detections of Phytophthora in container stock often results in the destruction of large blocks of nursery stock, our work focused on active
Phytophthora infections in roots, crowns, and stems. A much greater number and diversity of Phytophthora species would likely have been detected if the root and crown samples had been baited with pears instead of cultured from or extracted for DNA directly from the plant tissue.

Although the presence of Phytophthora species in commercial nurseries in the United States and Europe is well documented (Bienapfl and Balci 2014; Dart and Chastagner 2007; Junker et al. 2016; Knaus et al. 2015; Parke et al. 2014; Patel et al. 2016; Schwingle et al. 2007; Yakabe et al. 2009), this limited survey of 26 native plant nurseries in California showed that most have Phytophthora spp. With the exception of $P$. tentaculata and $P$. parvispora, all the Phytophthora species identified in this study are widely known in the nursery trade in California and worldwide. Nursery workers can spread Phytophthora species by receiving and brokering material from other native plant nurseries or outside commercial nurseries. They can also, as we learned during this study, reuse pots, often from other outside sources, and potting mix without any prior treatment to eliminate plant pathogens. These practices have likely contributed to the spread of Phytophthora species, especially P. tentaculata, within the community of native plant nurseries. For nurseries to produce cleaner, healthier plants, safeguards must be taken during the production process to reduce and eliminate the potential pathways for Phytophthora infection. At that time, most native plant nursery workers were unfamiliar with the symptoms of soilborne diseases and had not been exposed to nursery best management practice (BMP) programs, which identify critical control points for Phytophthora introduction and spread. The unintended introduction of plant pathogens on infected nursery stock into natural habitats that may threaten native plant species is contrary to the mission and goals of the California Department of Water Resources, CDFA, local municipal water districts, and the California native plant industry. These groups work to protect, enhance, and restore environments, and in some cases, include perpetual commitments to responsibly manage wildlands and native plant species. Discussions are ongoing in California to establish a clean stock accreditation program to ensure the outplanting of disease-free native plants into the wildlands.

\section{Acknowledgments}

We thank Karen Suslow, Kristina Weber, and Marinell Soriano for their exceptional technical assistance, Genevieve Walden for her editing assistance and knowledge of California's native plants, Gloria Abad for use of her oomycete PCR primers, and Frank Martin for the use of his database of Phytophthora sequences.

\section{Literature Cited}

Baldwin, B. G. 2014. Origins of plant diversity in the California Floristic Province. Annu. Rev. Ecol. Syst. 45:347-369.

Baldwin, B. G., Goldman, D., Keil, D. J., Patterson, R., Rosatti, T. J., and Wilken, D., eds. 2012. The Jepson Manual. Vascular Plants of California, Thoroughly Revised and Expanded, 2nd Ed. University of California Press, Berkeley, CA.

Baldwin, B. G., Thornhill, A. H., Freyman, W. A., Ackerly, D. D., King, M. M., Morueta-Holme, N., and Mishler, B. D. 2017. Species richness and endemism in the native flora of California. Am. J. Bot. 104:487-501.

Bienapfl, J. C., and Balci, Y. 2014. Movement of Phytophthora spp. in Maryland's nursery trade. Plant Dis. 98:134-144.

Bilodeau, G. J., Martin, F. N., Coffey, M. D., and Blomquist, C. B. 2014 Development of a multiplex assay for genus- and species-specific detection of Phytophthora based on differences in mitochondrial gene order. Phytopathology 104:733-748.

Brasier, C. M. 2008. The biosecurity threat to the UK and global environment from international trade in plants. Plant Pathol. 57:792-808.

Cooke, D. E., Drenth, A., Duncan, J. M., Wagels, G., and Brasier, C. M. 2000. A molecular phylogeny of Phytophthora and related oomycetes. Fungal Genet. Biol. 30:17-32.

Cunniffe, N. J., Cobb, R. C., Meentemeyer, R. K., Rizzo, D. M., and Gilligan, C. 2016. Modeling when, where, and how to manage a forest epidemic, motivated by sudden oak death in California. Proc. Natl. Acad. Sci. USA 113:5640-5645

Dart, N. L., and Chastagner, G. A. 2007. High recovery rate of Phytophthora from containerized nursery stock pots at a retail nursery highlights potential for spreading exotic oomycetes. Online. Plant Health Prog. 8. 
Donahoo, R. S., and Lamour, K. H. 2008. Characterization of Phytophthora species from leaves of nursery woody ornamentals in Tennessee. HortScience 43:1833-1837.

Erwin, D. C., and Ribeiro, O. K. 1996. Phytophthora Diseases Worldwide. American Phytopathological Society, St. Paul, MN.

Farr, D. F., and Rossman, A. Y. 2017. Fungal Databases. Syst. Mycol. Microbiol. Lab., ARS, USDA. Retrieved 27 Nov 2017, from https://nt.ars-grin.gov/ fungaldatabases/.

Frankel, S., Swiecki, T., Bernhardt, E., Rooney-Latham, S., and Blomquist, C. 2015. Pest Alert: Phytophthora tentaculata. [Online publication $672 \mathrm{~KB}$ ]. USDA Forest Service, Pacific Southwest Research Station, Albany, CA. http://www.suddenoakdeath.org/wp-content/uploads/2015/02/P.tentaculata. Pest_.Alert_.022315.pdf

Goss, E. M., Larsen, M., Vercauteren, A., Werres, S., Heungens, K., and Grünwald, N. J. 2011. Phytophthora ramorum in Canada: Evidence for migration within North America and from Europe. Phytopathology 101:166-171.

Grünwald, N. J., Garbelotto, M., Goss, E. M., Heungens, K., and Prospero, S. 2012. Emergence of the sudden oak death pathogen Phytophthora ramorum. Trends Microbiol. 20:131-138.

Hardham, A. R. 2005. Phytophthora cinnamomi. Mol. Plant Pathol. 6:589-604.

Hoitink, H. A. J., and Schmitthenner, A. F. 1974. Relative prevalence and virulence of Phytophthora species involved in rhododendron root rot. Phytopathology 64:1371-1374.

Jeffers, S. N., and Martin, S. B. 1986. Comparison of two media selective for Phytophthora and Pythium species. Plant Dis. 70:1038-1043.

Jepson Flora Project. Jepson eFlora 2017. Accessed 27 Nov 2017. http://ucjeps. berkeley.edu/eflora/

Jung, T., Chang, T. T., Bakonyi, J., Seress, D., Pérez-Sierra, A., Yang, X., Hong, C., Scanu, B., Fu, C. H., Hsueh, K. L., Maia, C., Abad-Campos, P., Léon, M., and Horta Jung, M. 2017. Diversity of Phytophthora species in natural ecosystems of Taiwan and association with disease symptoms. Plant Pathol. 66:194-211.

Jung, T., Orlikowski, L., Henricot, B., Abad-Campos, P., Aday, A. G., Aguín Casal, O., Bakonyi, J., Cacciola, S. O., Cech, T., Chavarriaga, D., Corcobado, T., Cravador, A., Decourcelle, T., Denton, G., Diamandis, S., Doğmuş-Lehtijärvi, H. T., Franceschini, A., Ginetti, B., Green, S., Glavendekić, M., Hantula, J., Hartmann, G., Herrero, M., Ivic, D., Horta Jung, M., Lilja, A., Keca, N., Kramarets, V., Lyubenova, A., Machado, H., Magnano di San Lio, G., Mansilla Vázquez, P. J., Marçais, B., Matsiakh, I., Milenkovic, I., Moricca, S., Nagy, Z. Á., Nechwatal, J., Olsson, C., Oszako, T., Pane, A., Paplomatas, E. J., Pintos Varela, C., Prospero, S., Rial Martínez, C., Rigling, D., Robin, C., Rytkönen, A., Sánchez, M. E., Sanz Ros, A. V., Scanu, B., Schlenzig, A., Schumacher, J., Slavov, S., Solla, A., Sousa, E., Stenlid, J., Talgø, V., Tomic, Z., Tsopelas, P., Vannini, A., Vettraino, A. M., Wenneker, M., Woodward, S., and Peréz-Sierra, A. 2016. Widespread Phytophthora infestations in European nurseries put forest, seminatural and horticultural ecosystems at high risk of Phytophthora diseases. For. Pathol. 46:134-163.

Junker, C., Goff, P., Wagner, S., and Werres, S. 2016. Occurrence of Phytophthora species in commercial nursery production. Plant Health Prog. 17:64-75.

Kamoun, S., Furzer, O., Jones, J. D., Judelson, H. S., Ali, G. S., Dalio, R. J., Roy, S. G., Schena, L., Zambounis, A., Panabieres, F., Cahill, D., Ruocco, M., Figueiredo, A., Chen, X. R., Hulvey, J., Stam, R., Lamour, K., Gijzen, M., Tyler, B. M., Grünwald, N. J., Mukhtar, M. S., Tome, D. F., Tor, M., Van den Ackerveken, G., McDowell, J., Daayf, F., Fry, W. E., Lindqvist-Kreuze, H., Meijer, H. J., Petre, B., Ristaino, J., Yoshida, K., Birch, P. R., and Govers, F. 2015. The top 10 oomycete pathogens in molecular plant pathology. Mol. Plant Pathol. 16:413-434.

Kang, S., Mansfield, M. A., Park, B., Geiser, D. M., Ivors, K. L., Coffey, M. D., Grünwald, N. J., Martin, F. N., Levesque, C. A., and Blair, J. E. 2010. The promises and pitfalls of sequence-based identification of plant-pathogenic fungi and oomycetes. Phytopathology 100:732-737.

Knaus, B. J., Fieland, V. J., Graham, K. A., and Grünwald, N. J. 2015. Diversity of foliar Phytophthora species on Rhododendron in Oregon nurseries. Plant Dis. 99:1326-1332.

Köppen, W. 1884. Translated by E. Volken and S. Brönnimann, "Die Wärmezonen der Erde, nach der Dauer der heissen, gemässigten und kalten
Zeit und nach der Wirkung der Wärme auf die organische Welt betrachtet" [The thermal zones of the earth according to the duration of hot, moderate and cold periods and to the impact of heat on the organic world.]. Meteorologische Z. published 2011. 20:351-360.

Kröber, K., and Marwitz, R. Z. 1993. Phytophthora tentaculata sp. nov. und Phytophthora cinnamomi var. parvispora var. nov., zwei neue Pilze von Zierpflanzen in Deutschland. Z. Pflanzenk. Pflanzen. 100:250-258.

MacDonald, J. D., Stites, J., and Kabashima, J. 1990. Comparison of serological and culture plate methods of detection species of Phytophthora, Pythium, and Rhizoctonia in ornamental plants. Plant Dis. 74:655-659.

Mascheretti, S., Croucher, J. P., Kozanitas, M., Baker, L., and Garbelotto, M. 2009. Genetic epidemiology of the sudden oak death pathogen Phytophthora ramorum in California. Mol. Ecol. 18:4577-4590.

Mascheretti, S., Croucher, J. P., Vettraino, A., Prospero, S., and Garbelotto, M. 2008. Reconstruction of the sudden oak death epidemic in California through microsatellite analysis of the pathogen Phytophthora ramorum.Mol. Ecol. 17: 2755-2768.

McGehee, C., and Raudales, R. E., and Elmer, W. H. 2018. First report of Pythium dissotocum caused by Pythium root rot on hydroponically grown lettuce in Connecticut. Plant Dis. 102:2043.

Migliorini, D., Ghelardini, L., Tondini, E., Luchi, N., and Santini, A. 2015. The potential of symptomless potted plants for carrying invasive soilborne plant pathogens. Divers. Distrib. 2015:1-12.

Parke, J. L., Knaus, B. J., Fieland, V. J., Lewis, C., and Grünwald, N. J. 2014 Phytophthora community structure analyses in Oregon nurseries inform systems approaches to disease management. Phytopathology 104:1052-1062.

Patel, J. S., Vitoreli, A., Palmateer, A. J., El-Sayed, A., Norman, D. J., Goss, E. M., Brennan, M. S., and Ali, G. S. 2016. Characterization of Phytophthora spp. isolated from ornamental plants in Florida. Plant Dis. 100:500-509.

Rizzo, D. M., Garbelotto, M., Davidson, J. M., Slaughter, G. W., and Koike, S. T. 2002. Phytophthora ramorum as the cause of extensive mortality of Quercus spp. and Lithocarpus densiflorus in California. Plant Dis. 86:205-214.

Rooney-Latham, S., and Blomquist, C. L. 2014. First report of root and stem rot caused by Phytophthora tentaculata on Mimulus aurantiacus in North America. Plant Dis. 98:996.

Rooney-Latham, S., Blomquist, C. L., Swiecki, T., and Bernhardt, E. 2015a. Phytophthora tentaculata. For. Phytophthoras 5.

Rooney-Latham, S., Blomquist, C. L., Swiecki, T., Bernhardt, E., and Frankel, S. J. 2015b. First detection in the US: New plant pathogen, Phytophthora tentaculata, in native plant nurseries and restoration sites in California. Native Plants J. 16:23-27.

Rubel, F., and Kottek, M. 2011. Comments on: 'The thermal zones of the Earth' by Wladimir Köppen (1884). Meteorologische Z. 20:361-365.

Scanu, B., Hunter, G. C., Linaldeddu, B. T., Francechini, A., Maddau, L., Jung, T., and Denman, S. 2014. A taxonomic re-evaluation reveals that Phytophthora cinnamomi and P. cinnamomi var. parvispora are separate species. For. Pathol. 44:1-20.

Schwingle, B. W., Smith, J. A., and Blanchette, R. A. 2007. Phytophthora species associated with diseased woody ornamentals in Minnesota nurseries. Plant Dis 91:97-102.

Stebbins, G. L., and Major, J. 1965. Endemism and speciation in the California flora. Ecol. Monogr. 35:1-35.

Swiecki, T. J., Bernhardt, E. A., Garbelotto, M., and Fichtner, E. J. 2011. The exotic plant pathogen Phytophthora cinnamomi: A major threat to rare Arctostaphylos and much more. Pages 367-371 in: Proceedings of the CNPS 2009 Conservation Conference: Strategies and Solutions. J. W. Willoughby, B. K. Orr, K. A. Schierenbeck, and N. J. Jensen, eds. California Native Plan Society, Sacramento, CA.

White, T. J., Brun, T., Lee, S., and Taylor, J. 1990. Amplification and direct sequencing of fungal ribosomal RNA genes for phylogenetics. Pages 315-322 in: PCR Protocols: A Guide to Methods and Applications. M. A. Innis, D. H. Gelfand, J. J. Sninsky, and T. J. White, eds. Academic Press, San Diego, CA.

Yakabe, L. E., Blomquist, C. L., Thomas, S. L., and MacDonald, J. D. 2009. Identification and frequency of Phytophthora species associated with foliar diseases in California ornamental nurseries. Plant Dis. 93:883-890.

Zadoks, J. C. 2008. The potato murrain on the European continent and the revolutions of 1848. Potato Res. 51:5-45. 